\title{
PENGENALAN EKSPRESI RAUT WAJAH BERBASIS JARINGAN SARAF TIRUAN BACKPROPAGATION DENGAN METODE PRINCIPAL COMPONENT ANALYSIS
}

\section{Facial Emotion Recognation Base Artificial Neural Network Backpropagation With Principal Component Analysis Method}

\author{
Harizahayu* \\ Prodi Manajemen Informatika Jurusan Teknik Komputer dan Informatika Politeknik Negeri Medan \\ Jl. Almamater No.1 Kampus USU, Medan, 20155, Indonesia
}

Corresponding author e-mail: * harizahayu@polmed.ac.id

\begin{abstract}
Abstrak
Perkembangan jaringan saraf tiruan berkaitan dengan analisis statistik dan biometrik yang merupakan salah satu aplikasi yang dapat diselesaikan dengan model- model jaringan saraf iruan. Pengenalan pola wajah merupakan bagian penting untuk mengidentifikasi seseorang. Wajah dapat dibagi menjadi beberapa area seperti hidung, mata, dan mulut. Pengenalan pola wajah merupakan suatu bidang penelitian yang dapat diterapkan ke dalam metode principal component analysis (PCA). Proses pelatihan yang dilakukan oleh perhitungan eigenface ini menggunakan PCA dan hasil penelitian ini memperlihatkan bahwa pengenalan pola wajah berdasarkan persentase memorisasi dan generalisasi untuk penggunaan metode tanpa PCA lebih baik dibandingkan denagn pengenalan pola wajah menggunkan PCA. Pengenalan pola tanpa menggunakan metode PCA tingkat memorisasi dan generalisasi mencapai $100 \%$ pada iterasi yang ke-40 dan kesalahan 0,0099 dengan laju pembelajaran dan momentum bernilai 0,8 sedangkan pengenalan pola wajah menggunakan metode PCA tingkat memorisasi dan generalisasi mencapai 100\% pada iterasi ke-1000 dan kesalahan 0,00103 dengan laju pembelajaran dan momentum 0,9.
\end{abstract}

Kata Kunci : Jaringan saraf tiruan, Principal Componen Analysis, Pengenalan pola wajah, Eigen value, Eigen vektor

\begin{abstract}
The development of artificial neural networks is related to statistical and biometric analysis which is one of the applications that can require artificial neural network models. Recognition of facial patterns is an important part of identifying a person. The face can be divided into areas such as the nose, eyes and mouth. Face pattern recognition is a research area that can be applied to the principal component analysis (PCA) method. The training process carried out by the eigenface calculation uses PCA and the results of this study show that facial pattern recognition based on the proportion of memorization and generalization for the use of the method without PCA is better than facial pattern recognition using PCA. Pattern recognition without using the PCA method, the level of memorization and generalization reaches $100 \%$ at the 40th iteration and 0.0099 error with a learning rate and momentum of 0.8 , while facial pattern recognition using the PCA method, the memorization and generalization level reaches $100 \%$ in the iteration. to -1000 and error 0.00103 with learning rate and momentum 0.9.
\end{abstract}

Keywords: Artificial Neural Network, Principal component analysis, Face recogniton, Eigen value, Eigen Vector

Article info:

Received: $21^{\text {st }}$ September $2020 \quad$ Accepted: $26^{\text {th }}$ February 2021

How to cite this article:

Harizahayu, "PENGENALAN EKSPRESI RAUT WAJAH BERBASIS JARINGAN SARAF TIRUAN BACKPROPAGATION DENGAN METODE PRINCIPAL COMPONENT ANALYSIS”, BAREKENG: J. Il. Mat. \& Ter., vol. 15, no. 1, pp. 037-046, Mar. 2021.

\section{(c) (†) ()}

This work is licensed under a Creative Commons Attribution-ShareAlike 4.0 International License.

Copyright $(2021$ Harizahayu 


\section{PENDAHULUAN}

Penelitian terhadap pengenalan pola wajah manusia adalah salah satu bidang penelitian penting yang aplikasinya dapat diterapkan dengan banyak metode yang memiliki kelebihan dan kekurangan tertentu. Hal ini disebabkan karena wajah manusia merepresentasikan sesuatu yang kompleks [1][2][3][4], sehingga untuk mengembangkan komputasi yang ideal pada pengenalan wajah adalah sesuatu hal yang sulit. Pengenalan Pola wajah dengan background, pencahayaan, ekspresi, kondisi atau rintangan yang berbeda sehingga membuat perbedaan pendekatan untuk pengelan pola wajah menjadi suatu eksperimen yang sangat menarik untuk diteliti [3]. Adapun perangkat lunak yang dipilih berasal dari MATLAB Image Processing Toolbox (IPT) [4] [5], yang juga menempati posisi terdepan dalam pendidikan dan industri menyediakan sebuah integrasi tanpa batas dari konsep teori yang mapan dan implementasinya menggunakan alat perangkat lunak tercanggih [1][6].

Perkembangan jaringan saraf tiruan yang berkaitan dengan analisis statistik dan biometrik merupakan salah satu aplikasi yang dapat diselesaikan dengan model-model jaringan saraf iruan. Sebuah ciri biologi yang dapat memberikan informasi untuk mengidentifikasi masing-masing individu. Dalam teknologi informasi, biometrik biasanya merujuk kepada teknologi yang mengukur dan menganalisis karakteristik tubuh manusia seperti sidik jari, retina, mata, pola suara, dan pola wajah yang terutama digunakan untuk proses otentifikasi [7][8]. Jaringan saraf tiruan mampu mengenali sesuatu dengan berbasis masa lalu. Hal ini berarti data masa lalu akan dipelajari sehingga mampu memberi keputusan terhadap data baru [9][10]. Objek penelitiannya berupa jaringan saraf tiruan bertujuan untuk memahami dan mengembangkan sistem pengenalan rumus dan simbol matematika. Adapun ketentuan prinsip kerja jaringan saraf, adalah fungsi jaringan saraf otak manusia [3][11]. Penjelasan representasi matematis dari pulsa yang melewati koneksi sinaptik neuron dan pemrosesannya untuk tindakan lebih lanjut. Hal ini membuat metode ini sangat berguna di era big data dan pengobatan yang dipersonalisasi latypora [11].

Banyak metode yang dapat digunakan untuk menganalisis pengenalan pola wajah, tetapi dalam penelitian ini hanya menggunakan metode principal component analysis (PCA) yang berbasis jaringan saraf tiruan (JST) membuat kinerja sistem lebih cepat dan akurat tanpa harus menghilangkan informasi yang penting pada data [3][9][10][12]. PCA yaitu suatu metode yang mampu mereduksi dimensi dari suatu objek, sehingga ukuran dari objek yang akan lebih ringkas dan mampu mengambil karakteristik yang penting dari suatu objek yang akan diolah. Jika dimensi dari objek lebih kecil dan informasi yang lebih padat, maka objek tersebut akan lebih spesifik dibanding objek yang diolah sebelumnya [8][13]. Pengenalan pola wajah merupakan suatu pengenalan pola (pattern recognition) yang khusus untuk kasus wajah [14]. Beberapa pendekatan untuk pengenalan objek dan grafika komputer didasarkan secara langsung pada citra-citra tanpa penggunaan model tiga dimensi [11]. Principal componenet analysis merupakan suatu metode yang mengekstraksi ciri atau kompresi data yang mampu mengidentifikasi ciri tertentu yang merupakan karakteristik dari suatu citra (dalam penelitian ini adalah wajah) [13][15].

Algoritme backpropagation merupakan suatu algoritme yang sangat baik dalam menangani masalah pengenalan pola-pola yang kompleks. Istilah backpropagation atau penyiaran kembali diambil dari cara kerja jaringan ini, yaitu gradient error unit output [2][6][16]. Hal ini karena nilai target untuk unit-unit tersembunyi tidak diberikan. Beberapa tahapan backpropagation yaitu dengan inisialisasi bobot, aktivasi, menghitung bobot input dan bias output dan perubahan bobot dan bias. Tahapan tersebut akan diperoleh output yang ingin dicapai dengan pendekatan error terkecil [5]. Pada jaringan saraf backpropagation ada beberapa faktor yang dapat diteliti untuk melakukan hal tersebut dengan menetapkan nilai learning rate $(\alpha)$ dan momentum $(\beta)$. Penentuan dan penyesuaian bobot laju pembelajaran (learning rate) yang cepat menentukan tercapainya tingkat konvergensi ke arah error yang diinginkan. Semakin besar nilai learning rate akan berimplikasi semakin besarnya pembelajaran [4].

Berdasarkan penelitian sebelumnya maka pada penelitian ini penulis memilih metode principal component analysis untuk mendeteksi pola wajah tanpa harus menghilangkan informasi yang ada pada data dan membandingkannya dengan pendeteksian pola wajah tanpa menggunakan metode PCA, sehingga dapat dijabarkan sebagai berikut: "Bagiamana kinerja jaringan saraf tiruan backpropagation untuk pengenalan pola wajah dengan metode principal component analaysis (PCA)". Sedangakan tujuan penelitian ini yang pertama adalah peneliti memahami dan mengamati konsep jaringan saraf tiruan dan proses algoritma backpropagation dengan menetapkan learning rate $(\alpha)$ dan momentum $(\beta)$ dan yang kedua peneliti membandingkan penggunaan metode principal component analysis dan tanpa penggunaan metode untuk data masukan pengenalan pola wajah pada jaringan saraf tiruan backpropagation. 


\section{METODE PENELITIAN}

Pada penelitian ini, digunakan 30 citra wajah yang terdiri dari 5 (lima ) orang. Setiap wajah orang diambil sampel sebanyak 6 (enam) citra dengan ekspresi yang berbeda-beda, dimana 4 citra digunakan sebagai tahap pelatihan (simple learning) dan 2 citra digunakan sebagai tahap pengujian (sample detection).

\subsection{Pengambilan Image Wajah}

Pengambilan image (gambar) wajah dilakukan dengan menggunakan kamera digital dengan format JPEG, mode RGB, dan beresolusi $640 \times 640$ terhadap 5 (lima) orang berdasarkan enam konfigurasi dasar wajah manusia secara psikologis, yaitu : kaget, marah, netral, tertawa, sedih, senyum, dan tertawa. Untuk memenuhi syarat penelitian ini, dilakukan perubahan terhadap karakteristik image wajah tersebut. Dengan menggunakan perangkat lunak Adobe Photoshop karakteristik image wajah tersebut diubah menjadi PCX, gray mode level 8 bit dan beresolusi $64 \times 64$. Pengambilan ciri wajah dilakukan dengan cara mengkroping citra beresolusi $30 \times 30$ dengan pusat kroping adalah koordinat hidung. Bagian wajah yang dikroping meliputi mata, hidung, dan mulut.

\subsection{Representasi Image dengan Principal Component Analysis}

Principal component analysis (PCA) adalah dengan memproyeksi image ke dalam ruang eigennya atau ruang wajah. Cara mendapatkannya adalah dengan mencari eigenvector yang dimiliki setiap image dengan memproyeksikan ke dalam ruang wajah [17]. Sasaran PCA dapat menangkap variasi total di dalam kumpulan wajah yang dilatihnya. Adapun langkah-langkah yang dilakukan PCA dalam proses pengenalan wajah adalah sebagai berikut:

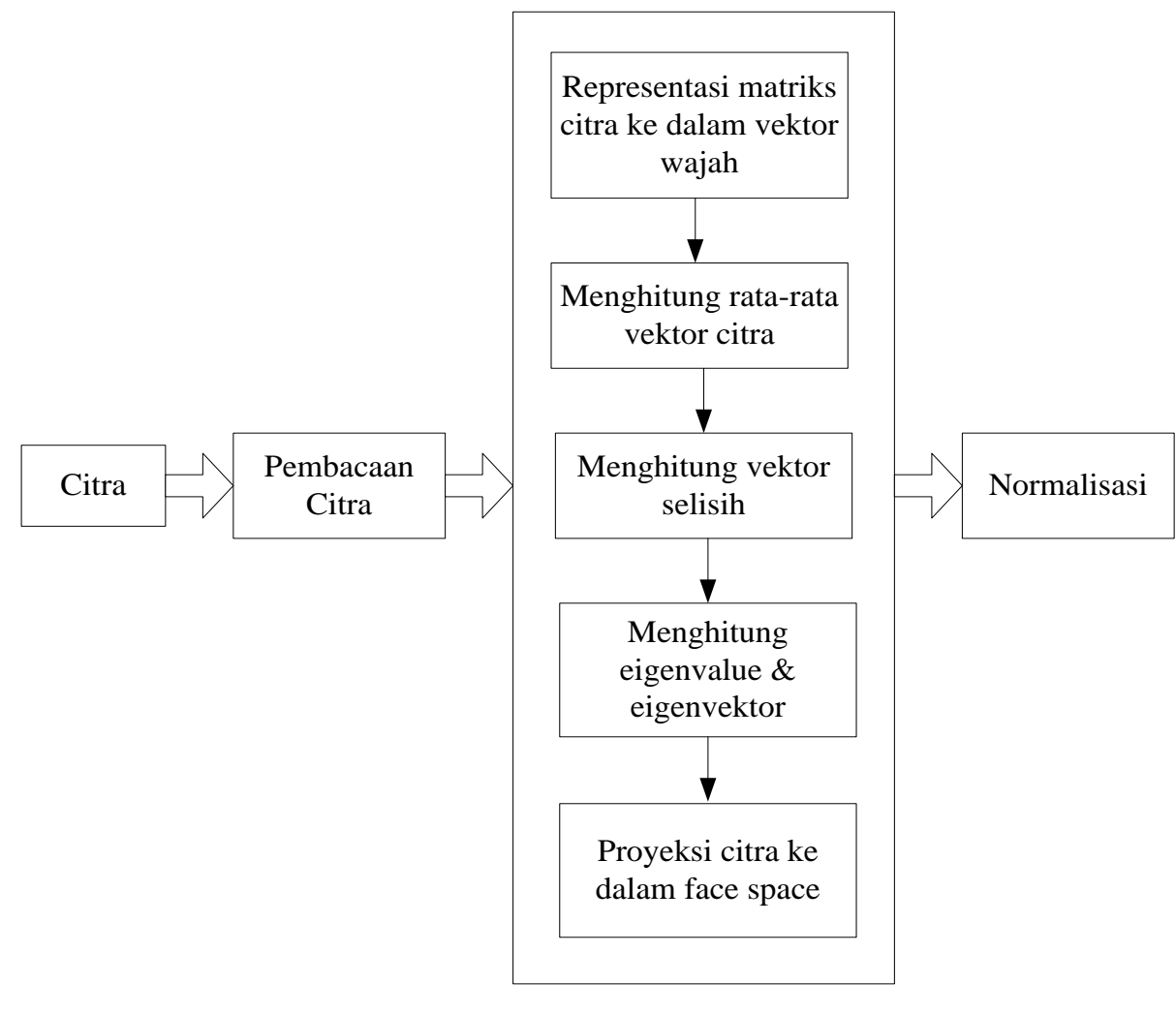

Metode PCA

\section{Gambar 1. Tahapan Pengolahan Citra}

Pembacaan citra merupakan proses perubahan image dari keadaan kontinu ke keadaan diskrit agar dalam ekstraksi dapat dimengerti oleh komputer. Hasil perubahan wajah terhadap sebuah citra wajah yang digunakan pada penelitian ini adalah matriks berukuran $30 \times 30$ yang berisi nilai-nilai diskrit dari setiap citra 
wajah. Peneliti menggunakan data tersebut dengan melakukan pelabelan terhadap citra wajah dengan cara sebagai berikut:

Tabel 1. Pelabelan Data Diskrit Citra Wajah

\begin{tabular}{|c|c|c|c|c|c|c|}
\hline \multirow[t]{2}{*}{ Objek } & \multicolumn{6}{|c|}{ Ekspresi Wajah } \\
\hline & Kaget & Marah & Netral & Sedih & Senyum & Tertawa \\
\hline Orang-1 & Foto-1A & Foto-2A & Foto-3A & Foto-4A & Foto-5A & Foto-6A \\
\hline Orang-2 & Foto-7A & Foto-8A & Foto-9A & Foto-10A & Foto-11A & Foto-12A \\
\hline Orang-3 & Foto-13A & Foto-14A & Foto-15A & Foto-16A & Foto-17A & Foto-18A \\
\hline Orang-4 & Foto-19A & Foto-20A & Foto-21A & Foto-22A & Foto-23A & Foto-24A \\
\hline Orang- 5 & Foto-25A & Foto-26A & Foto-27A & Foto-28A & Foto-29A & Foto-30A \\
\hline
\end{tabular}

Setelah semua citra dibaca oleh software readImage akan diperoleh file dari tiap citra yang berisi vektor-vektor yang mempunyai ukuran $30 \times 30$. Kemudian semua file dari tiap citra dibaca dengan Matlab 7.1 , yang menghasilkan vektor yang masing-masing berdimensi $N^{2} \times 1(N=$ ukuran dari masing-masing resousi citra). Vektor-vektor yang diperoleh digabungkan menjadi sebuah matriks berukuran $N^{2} \times 30$ untuk masing-masing resolusi citra yang disimpan ke dalam file "datal".

Tahap kedua adalah Perhitungan noise pada vektor tou merupakan data training dan membuat vektor baru (phi) yang merupakan vektor tau yang bebas dari noise dengan menghitung nilai pembeda (eigen value) antara vektor satu dengan vektor yang lain membuat eigen vector $\left(V_{\text {eigen }}\right)$ yang diurutkan (GoodV) berdasarkan eigen value terbesar dan membentuk principal component analysis (construct) yang telah tereduksi ukurannya (extract).

Dalam aljabar linier [3][18], Vektor eigen dari operator linier adalah vektor bukan-nol yang, bila dioperasikan untuk menghasilkan kelipatan skalar darinya. Skalar inilah yang kemudian disebut dengan nilai eigen $(\lambda)$ yang dikaitkan dengan vektor eigen. Vektor eigen adalah vektor yang diskalakan dengan transformasi linier. Ini adalah properti matriks, ketika matriks bekerja di atasnya, hanya besaran vektor yang berubah bukan arahnya.

$$
\begin{aligned}
& A X=\lambda X \quad, A \text { adalah sebuah fungsi vektor } \\
& (A-\lambda I) X=0, I \text { adalah matriks identitas }
\end{aligned}
$$

Persamaan (2) adalah sistem persamaan homogen yang membentuk fundamental aljabar linier. Diketahui bahwa solusi non trivial ada jika dan hanya jika $\operatorname{Det}(A-\lambda I)=0$, di mana $\operatorname{Det}$ menunjukkan determinan. Ketika persamaan $\operatorname{Det}(A-\lambda I)=0$ dievaluasi menjadi apolinomial yang berderajat $n$ maka persamaan disebut polinomial karakteristik $A$. Jika adalah $N$ untuk $N$ maka ada $n$ solusi atau $n$ akar polinomial karakteristik [19]. Jadi ada $n$ nilai eigen dari A yang memenuhi persamaan tersebut.

$$
A X_{i}=\lambda_{i} X_{i}, \quad i=1,2, \cdots, n
$$

Jika semua nilai eigen berbeda, ada $n$ vektor eigen yang bersifat independen linier terkait, arahnya unik dan menjangkau $n$ dimensi ruang euclide [3].

Himpunan data training dari $m$ images yang berukuran $N \times N$ yang diwakilkan dengan vektor berukuran $N^{2}$. Tiap-tiap wajah direpresentasikan oleh $\Gamma_{1}, \Gamma_{2}, \Gamma_{3}, \cdots, \Gamma_{m}$. Fitur Vektor dari sebuah face disimpan dalam matriks $N \times N$. Sekarang, vektor dua dimensi ini diubah menjadi vektor satu dimensi [20].

\section{Contoh:}




$$
\left[\begin{array}{ll}
1 & 2 \\
2 & 1
\end{array}\right]=\left[\begin{array}{l}
1 \\
2 \\
2 \\
2
\end{array}\right]
$$

Tiap-tiap gambar wajah direpresentasikan dengan vektor $\Gamma_{i}$.

$$
\Gamma_{1}=\left[\begin{array}{c}
1 \\
-2 \\
1 \\
-3
\end{array}\right], \Gamma_{2}=\left[\begin{array}{c}
1 \\
3 \\
-1 \\
2
\end{array}\right], \Gamma_{3}=\left[\begin{array}{c}
2 \\
1 \\
-2 \\
3
\end{array}\right], \cdots, \Gamma_{m}=\left[\begin{array}{l}
1 \\
2 \\
2 \\
1
\end{array}\right]
$$

Principal Component Analysis menggunakan nilai intensitas piksel dari citra yang akan ditampung ke dalam matriks berikut ini [7]:

$$
\Gamma=\left[\begin{array}{llll}
\Gamma_{0} & \Gamma_{1} & \cdots & \Gamma_{M-1}
\end{array}\right]
$$

Dengan mengasumsikan variabel-variabel, sebagai berikut :

$\Gamma$ : vektor citra input berdimensi $1 \times N^{2}$

$M$ : jumlah data dari input citra

Rata-rata gambar wajah dari semua vektor tou yang dihitung dengan persamaan berikut:

$$
\begin{aligned}
& \psi=\frac{1}{30} \sum_{i=0}^{M-1} \Gamma_{i} \\
& \qquad\left[\begin{array}{c}
1 \\
-2 \\
1 \\
3
\end{array}\right]+\left[\begin{array}{c}
1 \\
3 \\
-1 \\
2
\end{array}\right]+\left[\begin{array}{c}
2 \\
1 \\
-2 \\
3
\end{array}\right]+\cdots \rightarrow\left[\begin{array}{l}
1 \\
2 \\
2 \\
1
\end{array}\right] \\
& \psi=\frac{\left(\Gamma_{1}+\Gamma_{2}+\Gamma_{3}+\cdots+\Gamma_{M}\right)}{M}
\end{aligned}
$$

Dengan mengasumsikan variabel-variabel, sebagai berikut :

$\psi$ : nilai rata-rata citra

$M$ : jumlah dari citra input

$\Gamma$ : image vektor berdimensi $1 \times N^{2}$

Sehingga diperoleh vektor psi yang berukuran $N^{2} \times M[21]$

$$
\psi=\left[\begin{array}{llll}
\psi_{1} & \psi_{2} & \cdots & \psi_{M}
\end{array}\right]
$$

Semua vektor yang telah diperoleh disimpan ke dalam sebuah matriks bernama "Matriks psi" dalam file "data2", dimana $\psi_{1}, \psi_{2}, \psi_{3}, \cdots, \psi_{30}$ adalah rata-rata gambar pertama, kedua, ketiga sampai dengan gambar ketiga puluh pada penelitaian ini. Setelah diperoleh nilai noise (psi) untuk vektor tau, maka disusun vektor baru phi yang merupakan vektor tau yang bebas noise dan dihitung dengan rumus sebagai berikut [16]:

$$
\phi_{i}=\Gamma_{i}-\psi
$$

Tiap-tiap gambar terdiri dari rata-rata dengan $\Phi=\Gamma_{i}-\psi$ yang disebut dengan mean center image.

$$
\Phi_{1}=\left[\begin{array}{c}
2 \\
-1 \\
-1 \\
0
\end{array}\right] \Phi_{2}=\left[\begin{array}{c}
2 \\
4 \\
-3 \\
5
\end{array}\right] \Phi_{3}=\left[\begin{array}{c}
3 \\
2 \\
-4 \\
6
\end{array}\right] \cdots \Phi_{M}=\left[\begin{array}{l}
2 \\
3 \\
0 \\
4
\end{array}\right]
$$

Dengan mengasumsikan variabel-variabel, sebagai berikut :

$\phi:$ jarak perbedaan citra dengan nilai rata-rata citra

$\Gamma$ : vektor citra input berdimensi $1 \times N^{2}$

$\Psi$ : nilai rata-rata citra 
Vektor- vektor yang diperoleh digabung menjadi sebuah matriks berukuran $1 \times 900$. Semua vektor yang telah dipeoleh disimpan ke dalam sebuah matriks bernama "Matriks A" dalam file "data3". Karena dimensi matriks $A$ masih cukup besar untuk menghitung determinan matriks digunakan bantuan software Matlab untuk menghitungnya dengan $\operatorname{sintax} \chi=e i g(A)$. Untuk menghitung vektor eigen digunakan rumus sebagai berikut [3]:

$$
(\lambda . I-A) \cdot x=0
$$

Dengan mengasumsikan variabel-variabel, sebagai berikut :
$\lambda$ : nilai eigen
$I$ : matriks identitas
A: matriks kovarians
$x$ : vektor eigen

Matriks covariace $(C)$ tersebut merupakan matriks persegi yang disimpan ke dalam file "data4". $A$ adalah matriks kovarian yang dikosntruksikan sebagai berikut $C=A A^{T}$

Dimana matriks $A=\left[\Phi_{1}, \Phi_{2}, \Phi_{3}, \cdots, \Phi_{M}\right]$, dengan ukuran matriks $N^{2} \times N^{2}$.

$$
A=\left[\begin{array}{cc}
2 & 3 \\
-1 & -2 \\
-1 & 1 \\
0 & 2
\end{array}\right], A^{T}=\left[\begin{array}{cccc}
2 & -1 & -1 & 0 \\
3 & -2 & 2 & 2
\end{array}\right]
$$

Ukuran matriks kovarians akan menjadi $N^{2} \times N^{2}$ (matriks berkuran $30 \times 30$ dipenelitian ini). Vektor eigen yang sesuai dengan matriks kovarians ini perlu dihitung, tetapi itu akan menjadi tugas yang berat. Untuk mempermudah, kami menghitung $A^{T} A$ yang akan menjadi matriks $2 \times 2$ dalam kasus ini [3].

$$
A^{T} A=\left[\begin{array}{cc}
6 & 7 \\
7 & 18
\end{array}\right]
$$

Diasumsikan eigenvector $v_{i}$ dari $A^{T} A$, sehingga

$$
A^{T} A X_{i}=\lambda_{i} X_{i}
$$

Vektor eigen $v_{i}$ dari $A^{T} A$ adalah $X_{1}$ dan $X_{2}$ berukuran $2 \times 1$. Sekarang kalikan kedua ruas $A$ ke persamaan (), sehingga diperoleh

$$
\begin{gathered}
A A^{T} A X_{i}=A \lambda_{i} X_{i} \\
A A^{T}\left(A X_{i}\right)=\lambda_{i}\left(A X_{i}\right)
\end{gathered}
$$

Vektor eigen yang sesuai dengan $A A^{T}$ sekarang dapat dengan mudah dihitung dengan dimensi tereduksi di mana $A X_{i}$ adalah vektor Eigen dan $\lambda_{i}$ adalah nilai Eigen.

Tahap ketiga adalah normalisasi yang digunakan untuk menghasilkan output pada jaringan saraf tiruan. Pada penelitian ini normalisasi diperoleh dengan mengonversikan nilai principal component (extract) menjadi nilai bipolar antara -1 sampai dengan 1 , hal ini dilakukan karena JST menggunakan nilai input bipolar. Proses konversi ini dinamakan normalisasi yang rumus perhitungannya adalah sebagai berikut :

$$
\text { Normalisasi }_{i}=-1+\left(\frac{2}{\text { extract }_{\text {max }}-\text { extract }_{\text {min }}}\right)\left(\text { extract }_{i}-\text { extract }_{\text {min }}\right)
$$

Semua vektor yang telah diperoleh disimpan ke dalam sebuah matriks bernama "normalisasi" dalam file "data5".

\subsection{Penggunaan Arsitektur Jaringan saraf backpropagation}

Backpropagation merupakan algoritme pembelajaran yang terawasi dan biasanya digunakan oleh perceptron dengan banyak lapisan untuk mengubah bobot-bobot yang terhubung dengan neuron-neuron yang ada pada lapisan tersembunyi. Metode pembelajaran pada jaringan saraf tiruan disebut terawasi jika output telah diketahui [2][12]. 


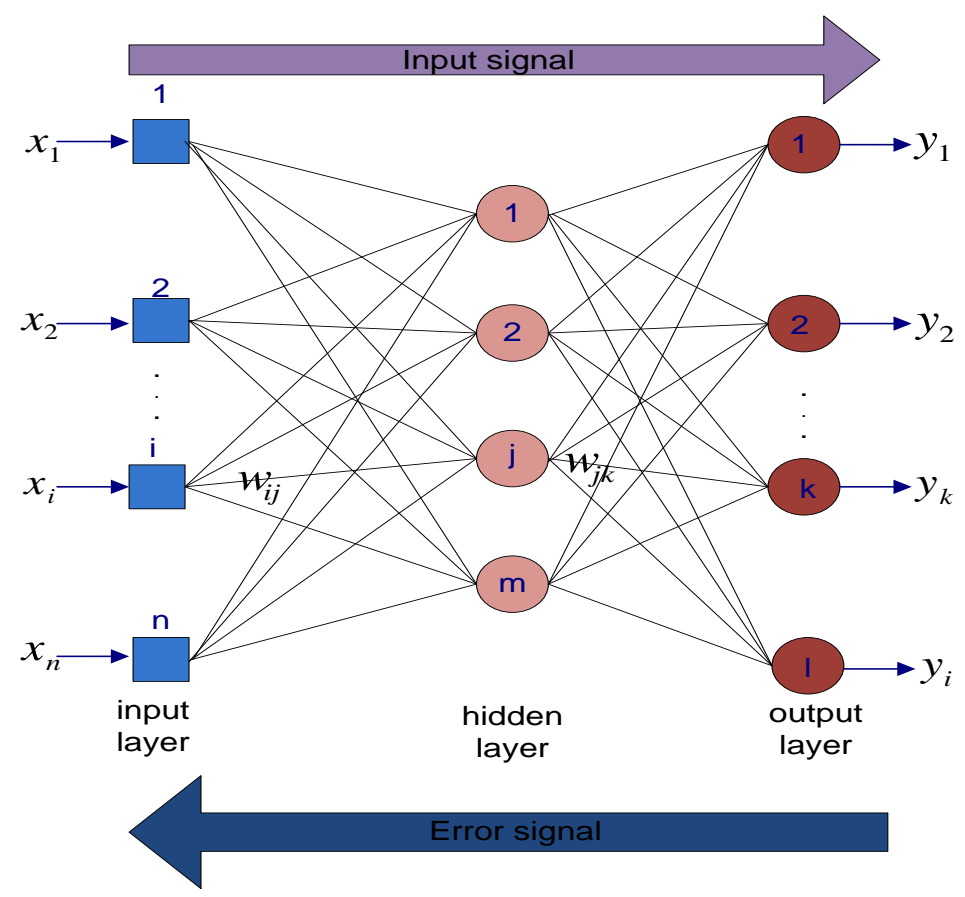

Gambar 2. Arsitektur Jaringan Saraf Backpropagation

Arsitektur jaringan saraf backpropagation 1 hidden layer terdiri atas 3 (tiga) lapis (layer) yaitu lapisan masukan (input layer) $x_{i}$, lapisan tersembunyi (hidden layer) $Z_{j}$, dan lapisan keluaran $y_{k}$ Input layer dan hidden layer dihubungkan dengan penimbangan $w_{i j}$ dan antara hidden layer dan output layer dihubungkan dengan $w_{j k}$. Pada pelatihan backpropagation, ketika jaringan saraf tiruan (JST) diberi pola masukan sebagai pola pelatihan maka pola tersebut akan menuju ke unit pada hidden layer untuk diteruskan pada unit output layer merupakan output layer $\left(y_{1}, y_{2}, \cdots, y_{k}, y_{i}\right)$ Keluaran sementara pada hidden layer $u_{j}$ akan diteruskan pada unit hidden layer dan hidden layer akan memberikan tanggapan yang disebut sebagai keluaran sementara $u_{k}^{\prime}$ Ketika $u_{k}^{\prime} \neq o_{k}$, dimana $o_{k}$ adalah keluaran yang diharapkan maka selisih (error) output sementara $u_{k}^{\prime \prime}$ akan disebarkan mundur (backward) pada hidden layer yang akan diteruskan ke unit input layer. Oleh karena itu proses tersebut disebut propagasi balik (backpropagation) dimana tahap pelatihan dilakukan dengan mengubah penimbangan yang menghubungkan unit dalam lapisan JST ketika diberi umpan maju dan umpan balik [22][23].

\section{HASIL DAN PEMBAHASAN}

Setelah dilakukan pelatihan dan pengujian diperoleh hasil penelitian klasifikasi error dengan menentukan besar nilai error dan tingkat penyimpangan yang secara terakumulasi membentuk pengenalan pola wajah. Sedangkan untuk memudahkan analisa, peneliti menampilkan hasilnya dalam bentuk Grafik 3 dan Tabel 2, sebagai berikut:

\subsection{Pelatihan Pola Wajah Pada Jaringan Saraf Tiruan Menggunakan Metode Principal Component Analysis}

Penelitian pada jaringan saraf backpropagation dengan menggunakan metode Principal Component Analysis dilakukan berdasarkan penggunaan nilai laju pembelajaran momentum. Hasil penelitian untuk arsitektur jaringan saraf dengan menggunakan PCA adalah sebagai berikut : 
Tabel 2. Hasil Penelitian Menggunakan Metode PCA

\begin{tabular}{llllllllll}
\hline Laju Pembelajaran $(\boldsymbol{\alpha})$ & 0,1 & 0,2 & 0,3 & 0,4 & 0,5 & 0,6 & 0,7 & 0,8 & 0,9 \\
\hline Momentum $(\boldsymbol{\beta})$ & 0,1 & 0,2 & 0,3 & 0,4 & 0,5 & 0,6 & 0,7 & 0,8 & 0,9 \\
\hline Epoch & 1000 & 1000 & 1000 & 1000 & 1000 & 1000 & 1000 & 1000 & 1000 \\
\hline Error & 3,0625 & 0,7057 & 0,2641 & 0,1144 & 0,0527 & 0,0317 & 0,0200 & 0,0138 & 0,0103 \\
\hline Memorisasi & $70 \%$ & $95 \%$ & $100 \%$ & $100 \%$ & $100 \%$ & $100 \%$ & $100 \%$ & $100 \%$ & $100 \%$ \\
\hline Generalisasi & $60 \%$ & $60 \%$ & $70 \%$ & $70 \%$ & $70 \%$ & $100 \%$ & $50 \%$ & $60 \%$ & $60 \%$ \\
\hline
\end{tabular}

Hasil percobaan di atas menunjukkan bahwa kesalahan pelatihan yang dihasilkan dari setiap percobaan terus menurun. Hasil percobaan terbaik dengan nilai error terdapat pada laju pembelajaran $(\alpha)=0,6$ untuk kesalahan pelatihan yang dicapai adalah 0,0317 , dengan epoch $=1000$ kali pengulangan dan kemampuan memorisasi jaringan dan generalisasi jaringan mencapai 100\%. Sedangkan untuk melakukan pengamatan terhadap konvergensi jaringan dapat dilakukan melalui pengamatan terhadap Gambar 3, berikut ini:

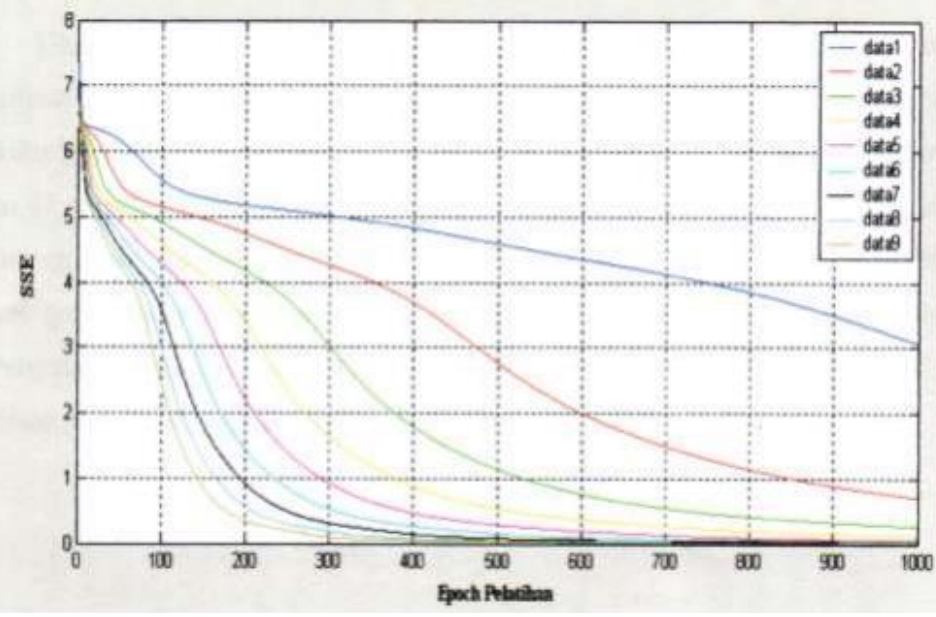

Gambar 3. Grafik Pelatihan dengan Metode PCA

Berdasarkan Gambar 3, dapat dilihat bahwa tingkat konvergensi tertinggi terdapat pada data 6 dan kesalahan pelatihan yang dihasilkan pada setiap epoch pelatihan mengalami penurunan.

\subsection{Pelatihan Pola Wajah Pada Jaringan Saraf Tiruan Tanpa Metode Principal Component Analysis}

Proses mengamati pengaruh metode PCA pada jaringan saraf tiruan backpropagation pada pengenalan pola wajah pada jaringan saraf tanpa metode PCA. Hasil dari penelitian tersebut adalah sebagai berikut:

Tabel 3. Hasil Penelitian Tanpa Metode PCA

\begin{tabular}{llllllllll}
\hline Laju pembelajaran $(\boldsymbol{\alpha})$ & 0,1 & 0,2 & 0,3 & 0,4 & 0,5 & 0,6 & 0,7 & 0,8 & 0,9 \\
\hline Momentum $(\boldsymbol{\beta})$ & 0,1 & 0,2 & 0,3 & 0,4 & 0,5 & 0,6 & 0,7 & 0,8 & 0,9 \\
\hline Epoch & 485 & 224 & 139 & 98 & 73 & 58 & 41 & 40 & 35 \\
\hline Error & 0,0100 & 0,0100 & 0,0100 & 0,0100 & 0,0100 & 0,0098 & 0,0100 & 0,0099 & 0,0098 \\
\hline Memorisasi & $100 \%$ & $100 \%$ & $100 \%$ & $100 \%$ & $100 \%$ & $100 \%$ & $100 \%$ & $100 \%$ & $100 \%$ \\
\hline Generalisasi & $80 \%$ & $80 \%$ & $80 \%$ & $90 \%$ & $100 \%$ & $90 \%$ & $80 \%$ & $100 \%$ & $90 \%$ \\
\hline
\end{tabular}


Hasil percobaan di atas menunjukkan bahwa kesalahan pelatihan yang dihasilkan dari setiap percobaan terus menurun. Hasil percobaan terbaik dengan nilai error $\leq 0,005$ terdapat pada laju pembelajaran $(\alpha)=0,5$ untuk kesalahan pelatihan yang dicapai adalah 0,0100 , dengan epoch $=73$ kali pengulangan dan kemampuan memorisasi jaringan dan generalisasi jaringan mencapai $100 \%$. Sedangkan untuk pengamatan terhadap tingkat konvergensi jaringan dapat dilakukan melalui pengamatan terhadap grafik selama pelatihan pada Gambar 4, berikut ini:

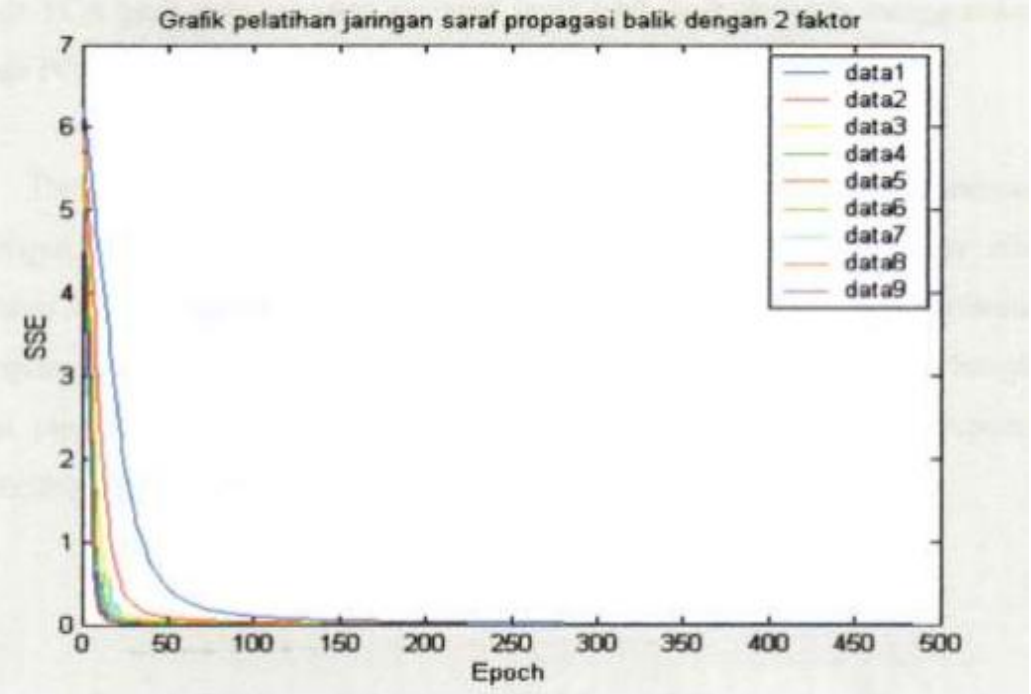

Gambar 4. Grafik Pelatihan Tanpa PCA

Berdasarkan grafik Gambar 4. Tingkat konvergensi jaringan selama pelatihan sangat baik karena setiap percobaan mengalami kovergensi yang baik sesuai dengan tingkat error yang diharapkan dan kesalahan pelatihan pada setiap epoch mengalami penurunan.

\section{KESIMPULAN}

Berdasarkan hasil simulasi pada uraian diatas, maka penelitian ini dapat ditarik kesimpulan:

1. Jaringan saraf tiruan merupakan metode yang baik dalam pengenalan pola wajah karena dapat mencapai kestabilan kembali untuk mencapai output yang diharapkan, hal ini karena adanya proses pemebelajaran dan pelatihan.

2. Penggunaan metode principal component analysis (PCA) dapat mereduksi matriks sesuai dengan jumlah data masukannya.

3. Pada kasus identifikasi pola wajah berdasarkan tingkat memorisasi dan generalisasi lebih baik tanpa menggunkan PCA.

4. Penggunaan learning rate dan momentum berpengaruh terhadap perubahan mean square error (MSE).

5. Semakin kecil tingkat ketelitian error yang digunakan, maka semakin kecil tingkat penyimpangan hasil jaringan saraf tiruan yang diinginkan target.

\section{DAFTAR PUSTAKA}

[1] I. Masi, Y. Wu, T. Hassner, and P. Natarajan, “Deep Face Recognition: A Survey,” 2019, doi: 10.1109/SIBGRAPI.2018.00067.

[2] I. kholis and A. Rofii, "Analisis Variasi Parameter Backpropagation Artificial Neural Network Pada Sistem Pengenalan Wajah Berbasis Principal Component Analysis,” J. Kaji. Tek. Elektro, vol. 2, no. 1, pp. 1-12, 2017.

[3] Fares Jalled, “Enhanced Reader.pdf,” Nature, vol. 388. pp. 1-14, 2017, [Online]. Available: http://arxiv.org/abs/1705.02782.

[4] S. Kusmaryanto, "Jaringan Saraf Tiruan Backpropagation untuk Pengenalan Wajah Metode Ekstraksi Fitur Berbasis Histogram," vol. 8, no. 2, pp. 193-198, 2014. 
[5] H. Oliveira and P. L. Correia, "CrackIT - An image processing toolbox for crack detection and characterization," 2014, doi: 10.1109/ICIP.2014.7025160.

[6] Y. Elviralita and A. Hidayat, "Identifikasi Pola Iris Menggunakan Metode Backpropagation," Manutech J. Teknol. Manufaktur, vol. 8, no. 02, pp. 43-48, 2019, doi: 10.33504/manutech.v8i02.21.

[7] W. Liu, Y. Wen, Z. Yu, M. Li, B. Raj, and L. Song, "SphereFace: Deep hypersphere embedding for face recognition,” 2017, doi: 10.1109/CVPR.2017.713.

[8] A. Vyas, S. Yu, and J. Paik, "Fundamentals of digital image processing," in Signals and Communication Technology, 2018.

[9] F. Hermawan, "Implementasi Jaringan Saraf Tiruan Backpropagation Untuk Mengenali Motif Batik," Ilm. Komput. dan Inform., 2014.

[10] H. Herman, L. Syafie, and D. Indra, "Pengenalan Angka Tulisan Tangan Menggunakan Jaringan Saraf Tiruan,” Ilk. J. Ilm., 2018, doi: 10.33096/ilkom.v10i2.317.201-206.

[11] A. Sinkov, G. Asyaev, A. Mursalimov, and K. Nikolskaya, "Neural networks in data mining," 2016, doi: 10.1109/ICIEAM.2016.7911596.

[12] A. Ghaseminejad and V. Uddameri, "Physics-inspired integrated space-time artificial neural networks for regional groundwater flow modeling," Hydrol. Earth Syst. Sci., vol. 24, no. 12, pp. 5759-5779, 2020, doi: 10.5194/hess-24-57592020 .

[13] J. O'Rourke and G. T. Toussaint, "Pattern recognition," in Handbook of Discrete and Computational Geometry, Third Edition, 2017.

[14] D. Erhan, C. Szegedy, A. Toshev, and D. Anguelov, "Scalable Object Detection Using Deep Neural Networks," in 2014 IEEE Conference on Computer Vision and Pattern Recognition, Jun. 2014, pp. 2155-2162, doi: 10.1109/CVPR.2014.276.

[15] N. Cintisa et al., "Pengenalan Ekspresi Pada Raut Wajah Pada Keselamatan Berkendara Menggunakan Principal Component Analysis ( Pca ) Dan Linear Discriminant Analysis ( Lda ) Facial Emotion Recognition for Safety Driving Using Principal," vol. 6, no. 3, pp. 10292-10300, 2019.

[16] V. Lopez-Pastor and F. Marquardt, "Self-learning Machines based on Hamiltonian Echo Backpropagation," 2021, [Online]. Available: http://arxiv.org/abs/2103.04992.

[17] V. S. Doan and D. S. Kim, "DOA estimation of multiple non-coherent and coherent signals using element transposition of covariance matrix," ICT Express, vol. 6, no. 2, pp. 67-75, 2020, doi: 10.1016/j.icte.2020.03.008.

[18] N. Das and R. Bhattacharya, "Eigen Value Analysis in Lower Bounding Uncertainty of Kalman Filter Estimates" no. January. pp. 104-107, 2020, [Online]. Available: http://arxiv.org/abs/2003.06029.

[19] R. Vahdani, H. Khalegi Bizaki, and M. J. Fall, "New correlated MIMO radar covariance matrix design with low side lobe levels and much lower complexity," Chinese J. Aeronaut., vol. 34, no. 1, pp. 327-335, 2021, doi: 10.1016/j.cja.2020.08.034.

[20] F. Nebus and S. Gažovová, "The covariance matrix analysis and statistics for near-field sources localization model," Adv Mil. Technol., vol. 15, no. 1, pp. 149-162, 2020, doi: 10.3849/aimt.01329.

[21] Ł. G. Gajewski, J. Chołoniewski, and M. Wilinski, “detected hidden layer.pdf." 2021, [Online]. Available: http://arxiv.org/abs/2101.11758.

[22] N. J. Guliyev and V. E. Ismailov, “Two_Hidden_Neurons.Pdf.” [Online]. Available: Guliyev, Namig J.\%0AIsmailov, Vugar E. 